\title{
Kırsal Turizm Planlaması Kapsamında Gastronomi Etkinliklerinin Değerlendirilmesi
}

\section{The Evaulation of Gastronomic Events Within the Context of Rural Tourism Planning}

Öğr. Gör. Dr. Aynur GÜLENÇ BíRSEN

Necmettin Erbakan Üniversitesi

Turizm Fakültesi

E-posta: abirsen@konya.edu.tr

Orcid Id: 0000-0002-8847-9946
Doç. Dr. Abdurrahman DiNÇ

Necmettin Erbakan Üniversitesi

Turizm Fakültesi

E-posta: a.dinc@konya.edu.tr Orcid Id: 0000-0002-7539-6084

\section{Öz}

Çalışmanın amacı kırsal alanların turizm gelişimleri açısından gastronomi etkinliklerinin nasıl algılanması ve planlanması gerektiğini ortaya koymaktır. Nitel araştırma yaklaşımının benimsendiği çalışmada araştırma verileri doküman incelemesi yoluyla elde edilmiştir. Kanada ve Amerika kırsallarında düzenli olarak yapılan gastronomi etkinliklerine yönelik yapılan doküman incelemesinden elde edilen bulgular sonucunda Türkiye kırsallarında yemek kültüründen nasıl yararlanılabileceği hususunda stratejik planlama önerileri verilmiştir. Yapılan değerlendirmeler neticesinde kültürel ve gastronomi zenginliklerinin yapılacak kırsal ölçekli etkinliklerle değerlendirilmesinin bu alanların turistik gelişimleri açısından önemli olduğu sonucuna ulaşılmıştır. Ayrıca etkinliklerinin yürüme, tırmanış, bisiklet, olta balıkçılığı gibi çeşitli tamamlayıcı aktivitelerle desteklenmesi gerektiği vurgulanırken, çiftçi, esnaf, yerel halkın etkinliklerin planlanması ve yürütülmesi konusunda bilinçlendirilmelerinin gerekli olduğu sonucuna ulaşılmıştır.

Anahtar Kelimeler: Kırsal turizm, gastronomi, gastronomi etkinlikleri.

\section{Abstract}

The purpose of this study is to reveal how to perceive and plan gastronomic events in terms of tourism developments of rural areas. In the study in which the qualitative research approach is adopted, the research data is obtained through a document review. As a result of the findings from the literature review carried out for the gastronomic events which are regularly arranged in rural parts of Canada and America, strategic planning suggestions have been given about how food culture can be utilized in rural parts of Turkey. Consequently, it is concluded that the evaluation of cultural and gastronomic attractions with rural scale activities is important in terms of touristic development of these areas. It is also emphasized that these activities should be supplemented by various complementary activities such as walking, climbing, cycling, angling and it is necessary to make the farmers, tradesmen and local people conscious of the planning and execution of activities.

Key Words: Rural tourism, gastronomy, gastronomic events. 


\section{Giriş}

Günümüzde deniz, kum, güneş üçlüsüne dayanan kitle turizm destinasyonları çeşitli nedenlere bağlı olarak doğal ve kültürel çekiciliklerini zamanla kaybetmekte, giderek turist potansiyellerini ve rekabet güçlerini kaybetmektedirler (Uysal ve Baloğlu, 1994). Ayrıca seyahat beklentileri değişen, çevre bilinci yüksek tüketiciler de sıradanlaşan bu kitle turizmden sıkılmakta ve daha bireysel ürünler aramaktadır.

Turizmin olumsuz etkilerinin minimum seviyeye indirgenmesi kaynakların dengeli kullanılmasına, alternatif ürün çeşitlerinin oluşturulmasına, kırsal alanların turizmden ekonomik fayda sağlamalarına bağlıdır (Bahçe ve diğ., 2013). Tatil anlayışında küresel tek biçimlilik yaratan kitle turizminin aksine, kültürel bir unsurdan doğal güzelliğe, bir metropolden küçük bir köye, yağmur ormanlarından çöle, inançtan şarap veya kumara kadar çok geniş bir ürün yelpazesi sunan her bir alternatif turizm türünün pazar payı küçük olsa da toplamda oldukça büyüktür (Bahçe ve diğ., 2013). Ancak turizmin sürdürülebilir bir yapıda geliştirilebilmesi için doğal çevrenin korunması ve ilgili alanların sürdürülebilir turizm planlarının yapılması gerekmektedir (Özdemir, 2006).

Destinasyonların diğerlerinden farklılaştırılmasında yerel yiyecek-içecek ve mutfak kültürünün önemi büyüktür. Son yıllarda kaliteli yerel ürünlerin geliştirilerek pazarlandığı destinasyonlara yönelik turistik seyahatlerin hızla arttığı bilinmektedir. Kırsal alanların ekonomik gelişmesine katkısı olan yemek kültürü yöreye rekabet avantajı sağlamaktadır. Ancak, bu alanların ekonomik, kültürel ve çevresel açıdan kalkınabilmesi için gastronomi etkinliklerin stratejik olarak planlanması gerekmektedir (Lee, 2012).

Bu çalışmada, kırsal alanların sürdürülebilir kalkınmasında turistik bir ürün olarak yemek kültüründen nasıl faydalanılabileceği ve nasıl planlanabileceği kırsal turizm kapsamında araştırılmıştır. Bu amaçla Kanada ve Amerika kırsallarında düzenli olarak yapılan gastronomi etkinlikleri incelenmiştir. Elde edilen ipuçları neticesinde Türkiye kırsallarında sahip olunan kültürel ve gastronomi zenginliklerinin turistik çekicilikler kapsamında nasıl değerlendirilebileceği hususunda önerilerde bulunulmuştur.

\section{Kırsal Turizm}

Literatür kaynaklarında kırsal turizmin tanımıyla ilgili birçok görüş bulunmaktadır. Örneğin; Mihailovic (2012) kırsal turizmi "geleneksel tarım, kültür, doğal ve yerel kaynakları içine alan çok fonksiyonlu bir tür" olarak değerlendirmektedir. Chuang ise, yerel halkın yaşam tarzını, kültürünü koruması ve geleneksel tarımı sürdürmesi açısından bir fırsat olarak görmektedir (Yozukmaz ve diğ., 2014). Bir başka tanıma göre kırsal turizm; kırsal kültür, doğal çevre ve tarımla bütünleşen, ayrıca diğer turizm türleriyle kolay bir şekilde entegre olabilen bir turizm çeşidi olarak görülmektedir (Kesici, 2012). Ancak yapılan tanımlamaların ortak noktası bu türün, ziyaretçilerine sadece tarımsal tatil deneyimi yaşatmaktan ziyade, çok yönlü rekreatif etkinlikleri içeren, yerel halk ile iletişimi, halkın yaşamsal aktivitelerine katılımını sağlayan ve yerel kültüre ait deneyimler edindiren bir turizm çeşidi olmasıdır (Mac Donald ve Jolliffe, 2003; Baramwell ve Lane, 1994; Aref ve Gill, 2009).

Lane' e göre (1994), kırsal turizm;

- Kırsal alanlarda yapılmalı,

- Iş̧levsel olarak, kırsal özellikler üzerine kurulu olarak açık alanlarda yapılan, doğa, doğal hayat ve geleneksel halkın kültürel mirası ile iç içe olmalı, 
- Binalar ve yerleşkeler açısından kırsal ölçekte küçük çaplı olmalı,

- Karakteristik açıdan geleneksel, yavaş ve yapısını bozmadan ilerlemeli ve yerli halk ile birlikte yürütülmelidir. Bölgenin uzun vadede yararı için geliştirilmeli ve yerel yönetimlerce sık sık kontrol edilmelidir,

- Sürdürülebilir olmalı - bölgenin kırsal yapısı değişmemeli ve kaynakların kullanımı açısından da gelişimi sürdürülebilir olmalıdır. Kırsal turizm şehirleşme ve büyüme vesilesi olmak yerine, potansiyel bir koruma ve sürdürülebilirlik aracı olarak görülmelidir.

- Kırsal turizm pek çok çeşidiyle, bölgenin tarihini, ekonomisini ve karmaşık kırsal çevresini yansıtmalıdır (Kiper ve Özdemir, 2012).

Tablo 1: Kırsal Turizmde Yapılabilecek Etkinlik ve Hizmetler

\begin{tabular}{|c|c|c|}
\hline Bölge & Etkinlik & Hizmetler \\
\hline Yabani bitki toplama alanları & Yabani bitki toplama & $\begin{array}{l}\text { Gezi bilgisi, haritalar, yollar } \\
\text { ve tuvaletler }\end{array}$ \\
\hline Kırsal yaşam ve köy hayatı & $\begin{array}{l}\text { Geleneksel tarım etkinlikleri, } \\
\text { turlar }\end{array}$ & $\begin{array}{l}\text { Gezi bilgisi, haritalar, yollar } \\
\text { ve tuvaletler }\end{array}$ \\
\hline Olta balıkçılığı & Eko balıkçılığı & Park alanı ve çevre tasarımı \\
\hline Tarım ürünleri sergisi & $\begin{array}{l}\text { Tarım ürünleri ve geleneksel } \\
\text { eşya satışı }\end{array}$ & $\begin{array}{l}\text { Tarım ürünleri ve } \\
\text { geleneksel eşya satışı }\end{array}$ \\
\hline Yerel yemekler & $\begin{array}{l}\text { Yerel yemeklerle ilgili } \\
\text { bilgilendirme }\end{array}$ & $\begin{array}{l}\text { Tabelalar, park alanları, } \\
\text { hizmet binası, çevre } \\
\text { tasarımı }\end{array}$ \\
\hline Çiftliklerde konaklama & $\begin{array}{l}\text { Kırsal destinasyonda } \\
\text { konaklama }\end{array}$ & $\begin{array}{l}\text { Tabelalar, park alanları, } \\
\text { çevre tasarımı, konaklama } \\
\text { imkanlarının geliştirilmesi }\end{array}$ \\
\hline Şelaleler & Şelale gezileri & $\begin{array}{l}\text { Tabelalar, çevre tasarımı, } \\
\text { park alanları }\end{array}$ \\
\hline Yöre halkı ve yaşam alanları & $\begin{array}{l}\text { Kültür, dans, geleneksel } \\
\text { festivaller }\end{array}$ & $\begin{array}{l}\text { Gezi bilgisi, gezi rotaları, } \\
\text { sergi merkezi, müze, } \\
\text { festivaller ve park alanları }\end{array}$ \\
\hline Doğal manzara & Tırmanış ve gezi & $\begin{array}{l}\text { Patikalar, gezi rotalarıyla } \\
\text { ilgili tabelalar ve tehlike } \\
\text { uyarıları }\end{array}$ \\
\hline Kültürel miras alanları & $\begin{array}{l}\text { Kültürel mirasla ilgili anlatılar, } \\
\text { hikayeler }\end{array}$ & $\begin{array}{l}\text { Gezi bilgisi, haritalar, turist } \\
\text { rotaları }\end{array}$ \\
\hline
\end{tabular}

Kaynak: Kiper ve Özdemir, (2012)

\subsection{Kırsal Turizm Planlaması}

Turizmin sürdürülebilir bir yapıda geliştirilebilmesi için gelişmesini yok etmeden çevrenin korunması ve ilgili alanların planlanması gerekmektedir (Özdemir, 2006). Kırsal turizmin planlanmasında nüfus etkin rol oynamaktadır. Yoksulluk, toplum refahıyla ilgili kaynak eksikliği ve hizmetlerin yokluğu gibi etkenler kırsalda yaşayan nüfusun azalmasına sebep olmaktadır. Göçün azaltılması için, mevcut ekonomik, çevresel ve üretim potansiyellerinin optimum seviyede kullanılması önemlidir. Böylelikle yerel halkın gelir ve refah düzeyi de artacaktır. Dolayısıyla turizmin bir parçası olarak kırsal turizm bu alanların sosyo-ekonomik gelişimi için önemli bir araçtır (Mahmoudi ve diğ., 2011).

Yerel veya mahal planlama; belirli bir alan içinde bulunan çekiciliklerin, olanakların ve hizmetlerin bir turistik ürün oluşturmak üzere sürdürülebilirlik ilkeleri 
doğrultusunda ilişkilendirilmesi, programlanması ve örgütlenmesi çalışmalarıdır. Bu tür bir planlama, bir taraftan yerel halkı turizm kaynaklarına sahip çıkmaya özendirirken, diğer yandan da turistlere ulaşma olanağı sağlar. Dolayısıyla yerel planlama sürecinde hem turistlerin tercihleri hem de yerel halkın istekleri ve tercihleri inmal edilmemelidir (Soykan, 2000). Kırsal turizmin planlanmasıyla ilgili çeşitli bakış açıları vardır. Örneğin Lane, sürdürülebilir başarılı bir kırsal turizm planlaması için dört hususun önemine işaret etmektedir. Bunlar;

- Stratejiyi oluşturacak kişi ya da gruplar sadece turizm planlamasında değil, aynı zamanda ekonomi, çevrebilim ve sosyal analiz gibi konulara da hakim olmalıdırlar.

- Tüm ilgi grupları arasında işbirliği önemlidir.

- Başarılı bir turizm planı için en önemli şey planlamanın yerel halk ve bölge yararına olmasıdır. Bu açıdan yerel halk memnuniyeti için uygun stratejiler geliştirilmelidir.

- Strateji geliştirme süreci bir defaya mahsus değil uzun süreli olmalıdır. Ayrıca değişikliklere adapte olunabilmeli, hatalar ve eksiklikler kabul edilebilmelidir (Lane, 1994, 2005).

Diğer taraftan Hong'a göre kırsal turizm planlaması;

- Amaçların belirlenmesi,

- Konuyla ilgili turizm kanun ve yönetmeliklerin analizi,

- Kırsalda bulunabilecek potansiyellerin ve tarım turizmi için yapılabilecek aktivitelerin değerlendirilmesi,

- Ayrıntılı bir planlama programı için önemli sınıflandırma ve alanların seçimi,

- Farklı bölgeler için ayrıntılı geliştirme programları,

- Ekonomik sonuçlar ve diğer kazançlar ile ilgili analiz süreçlerinden oluşmaktadır (Hong, 1998). 
Şekil 1: Kırsal Turizm Planlaması

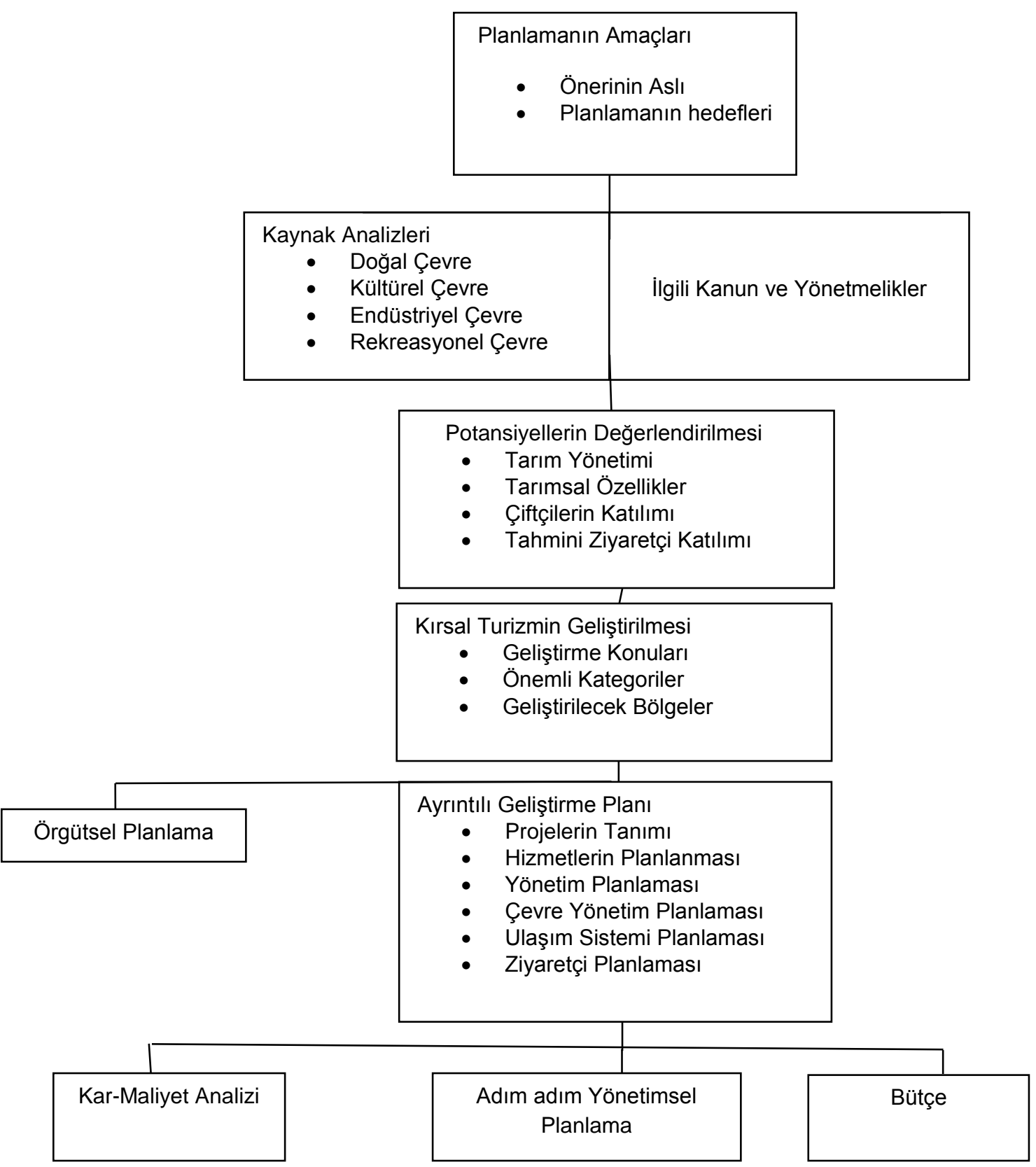

Kaynak: Hong, W-C.(1998).Rural Tourism: A Case Study of Regional Planning in Taiwan.(Online) http://fftc.imita.org/htmlarea file/library/20110726110810/eb456.pdf.Erișim:11.01.14

\section{Gastronomi Turizmi}

Gastronomi, iyi yemek yeme ve bütünüyle yemek yeme ile ilgili mutluluk arayışı olarak tanımlanabilir (Kalinia, 2013). Diğer taraftan gastronomi turizmi ise; ana motivasyon kaynağı olan özel bir yemeğin tadımını veya bir yemeğin üretim aşamalarını görmek amacıyla yöresel veya kırsal alanları, yiyecek üreticilerini, restoranları, yemek 
festivallerini ve özel alanları ziyaret etmek olarak açıklanmaktadır (Deveci ve diğ., 2013). Bu turizm çeşidi; farklı tatları denemeyi, restoran gezilerini, gösterileri, çiftçi pazarlarını, panayırları, gastronomi festivallerini, yiyecek ya da yemek yeme ile ilgili diğer etkinlikleri ya da turistik etkinlikler gibi farklı türleri kapsayabilir (Hall ve diğ., 2003).

Yemek yemenin turistik davranışları etkileme boyutuna göre turizm çeşitleri, şu kriterler dikkate alınarak sınıflandırılabilir;

a) Seyahat etmede yiyeceğin belirleyici unsur olduğu turizm çeşitleri,

- Gurme turizm

- Gastronomi turizmi

- Mutfak turizmi

b) Seyahat etmede yiyeceğin ikinci derecede önemli olduğu turizm türleri,

c) Yemek ve değişik tatlarla ilgili deneyim isteğinin turistlerin seyahat nedenlerinde belirleyici olduğu turizm türleri (Hall ve diğ., 2003; Matlovicova ve Pompura, 2013).

Tikkanem (2007), turizm ve gastronomi ile ilgili dört husustan bahseder. Bunlar; gastronominin turizmin bir parçası olması, destinasyonun tanıtımında çekici bir unsur olması, yeme içme deneyiminde yerel mutfağın kullanılması ve yerel kültürün bir parçası olmasıdır (Çalışkan, 2013).

Gastronomi turizmi her ne kadar akademik açıdan yeni bir araştırma alanı olsa da, otantik yiyecekleri tatmak literatür kaynaklarına göre gittikçe artan oranda seyahat etme davranışının ana sebebi ya da önemli bir sebebi olarak görülmektedir. Ülkemizde yapılan bir araştırmaya göre; Türkiye'yi ilk defa ziyaret eden turistlerin bu ziyaretlerini tekrarlama nedenlerinden birisinin ülkemizdeki yiyecek kalitesi olduğu vurgulanmıştır (Okumuş ve diğ., 2007). Başka bir araştırmada Hong Kong' un ziyaret edilmesinde yiyecek 2. sırada önemli görülürken, Bangkok'ta 4. , Singapur' da 5. sırada önemli bulunmuştur (Enright ve Newton, 2005).

\subsection{Kırsal Turizm ve Gastronomi Turizmi Arasındaki İlişki}

Destinasyon seçimini etkileyen en önemli sebeplerden birisi de yemektir (Ardabili ve diğ., 2011). Bu sebeple, sahip oldukları alternatif ürünlerle turizm piyasasına giren kırsal destinasyonlar, otantik ve nadir bulunan deneyimler yaşamayı, yerel ürünleri ve içecekleri yerinde tatmayı arzu eden potansiyel bir ziyaretçi kitlesine hitap edebilmek için yeme içme kültürlerini turistik ürün olarak değerlendirme çabasındadırlar. Araştırmacılara göre gastronomi turistleri ziyaret ettikleri kırsallara özgü yiyecek içecekleri tadarak ve kültürel bir takım otantik deneyimlerde bulunarak kendilerini o yerel kültürün içinde bulmayı ümit etmektedirler (MacDonald ve Deneault, 2001). Yerel ürünlerin satışı da bu destinasyonlara turistik açıdan bir kimlik oluşturma fırsatını sağlamaktadır (Everett ve Aitchison, 2008; Mason ve Paggiaro, 2009).

Günümüzde artan ekonomik, çevresel, sosyal gelişmeler ve sorunlar kırsal bölgeler üzerinde giderek baskı oluşturmakta sonuç olarak kırsal ekonomilerin yapısını ve kırsalda yaşayan yerel halkın yaşam şeklini değiştirmektedir. İşte bu aşamada sorunlarına çözüm arayışı içinde olan destinasyonlar için turizm, ekonomik bir potansiyel ve bir çözüm aracı olarak görülmektedir. Dolayısıyla kırsal alanların sahip olduğu gastronomi kaynaklarının (çiftlik, köy gezileri, tarladan alışveriş imkanı ve yerel 
ürünler sunan restoran ziyaretleri, bilgilendirme ve eğitim gezileri vb.) gelir kaynaklarının çeşitlendirilmesi ve ekonomik gelişmenin sağlanması açısından potansiyel derecede önem arz etmesi şaşırtıcı bir durum değildir. Öte yandan kırsal alanlar gastronomiyi içine alan yerel kültürün orijinal olarak yaşandığı yerlerdir. Bu nedenle kırsal alanlardaki gastronomi değerleri şehir merkezindekilere göre daha değerlidir. Bu gerçeğin farkında olan ve özellikle artan oranda kentleşen toplumların olduğu batılı ülkelerde bulunan pek çok kırsal destinasyon, turistik kaynaklarını kullanarak, hem global hem de bölgesel anlamda uluslararası ve yerli turistler için önemli destinasyonlar haline gelmiştir (Hall ve diğ., 2003).

\section{Araştırmanın Yöntemi}

\subsection{Araştırmanın Amacı ve Önemi}

Ziyaretçiler, tatilleri süresince en fazla keyif aldıkları ve önemsedikleri aktivitelerden birisi olan yemek yemeye ilişkin harcamalarını azaltmayı pek fazla düşünmezler (Okumus ve diğ., 2007). Seyahat edilecek destinasyonun sahip olduğu çekicilikler içinde yer alan geleneksel yöresel yiyecekler ise ziyaretçilere otantik kültürel deneyimler kazandırmakta ve yörenin gastronomi kimliğinin oluşmasını sağlamaktadır. Öte yandan bu tür ziyaretler yerel ekonominin güçlenmesi ve turizmin sürdürülebilirliği için çok önemli katkılar getirmektedir (Rand ve diğ., 2003). Ancak son zamanlarda yöresel yiyeceklere ilgi artmakta ise de, pek çok kırsal destinasyon sahip oldukları yöresel ürünlerini pazarlama çabasına girmemekte ya da planlama hataları yaparak bu potansiyellerini avantaja dönüştürememektedirler. Oysa yerel yiyeceklerin satışı ve tüketilmesine yönelik etkili pazarlama yöntemleri sayesinde tüketicilerin ilgisi bu ürünlere çekilebilir.

Kendilerine bir kimlik oluşturarak sahip oldukları yöresel ürünlerini etkinlikler yoluyla tüketicilere sunan kırsal yörelerde uygulanan planlama stratejileri yerel üreticiler, imalatçılar, toptancılar, oteller, restoranlar, şarap imalathaneleri ve şeflerin ortak işbirliğiyle yapılmakta ve olumlu sonuçlar vermektedir (Okumus ve McKercher, 2007; Piebiak, 2008). Bu sebeple bölgelerini başarılı bir şekilde pazarlayabilmeyi başarmış destinasyon örneklerinin incelendiği bu çalışmanın Türkiye kırsallarında gastronomi etkinliklerinin nasıl algılanması ve planlanması gerektiği hususunda turizm planlamacılarına ve girişimcilere ışık tutacağı düşünülmektedir.

\subsection{Araştırmanın Yöntemi ve Kısıtları}

Araştırmada nitel araştırma yaklaşımından yararlanılmıştır. Nitel yaklaşım çerçevesinde veri toplama tekniği olarak doküman incelenmesi tercih edilmiştir. Nitel araştırmalarda sıkça tercih edilen bu yöntem, araştırılması hedeflenen olay ve olgulara ilişkin yazılı ve görsel materyallerin analizini kapsar (Yıldırım ve Şimşek, 2011: 187).

$\mathrm{Bu}$ araştırmada araştırmanın problemine ilişkin olarak doğrudan gözlem ya da görüşme olanağı olmamasından dolayı doküman incelemesi yöntemi tercih edilmiştir. Bu sebeple çalışma kapsamında öncelikle detaylı bir yazın taraması yapılmıştır. Kırsal destinasyonlarda yapılan çeşitli gastronomi etkinlik örneklerine ilişkin yerli ve yabancı yazında yapılmış önceki çalışmalar, ulusal-uluslararası raporlar, basılı ve elektronik dökümanlar incelenmiş ve elde edilen ikincil verilerle çalışmanın birinci ve ikinci bölümleri oluşturulmuştur.

Kanada ve Amerika Birleşik Devletleri kırsallarında düzenli olarak yapılan etkinliklerin incelendiği araştırmanın kapsamını bu ülkelerin sınırları içinde yer alan 
birkaç kırsal yerleşim alanı oluşturmaktadır. Bunun da sebebi araştırmanın amacına ilişkin olarak Türkiye' de düzenli olarak yapılan başarılı örnek uygulamalara ve planlama stratejilerine iliş̧kin yeterli veri kaynağına ulaşılamamış olmasıdır.

\section{Bulgular}

Günümüzde artık pek çok kırsal destinasyon yerel ekonomilerini geliştirmek için stratejiler oluşturmakta ve giderek artan oranda ulusal, bölgesel ve yerel yönetimlerce de desteklenmektedir. Gastronomi etkinliklerinin Türkiye kırsallarının turizm gelişimlerinin sağlanabilmesi açısından nasıl algılanması ve planlanması gerektiğinin ortaya çıkarılması amacıyla yapılan bu çalışmada Kanada ve Amerika Birleşik Devletleri kırsallarında düzenli olarak yapılan gastronomi etkinliklerinden bazıları ve bu etkinliklere ilişkin planlama yaklaşımları incelenmiştir. Elde edilen bulgular tablo 2, tablo 3 ve tablo 4 'te özetlenmektedir.

Tablo 2'de kırsallarda uygulanan gastronomi etkinliklerinin adı, kurucusu, nerede yapıldığı, en yakın şehre mesafesi ve etkinliğe katıım şartları gibi temel bilgilere yer verilmiştir.

Tablo 2: Etkinliklere İlişkin Temel Bilgiler

\begin{tabular}{|c|c|c|c|c|c|}
\hline $\begin{array}{l}\text { Etkinlik } \\
\text { Adı }\end{array}$ & Kurucu & $\begin{array}{l}\text { Yerleşke } \\
\text { Adı }\end{array}$ & $\begin{array}{l}\text { En yakın } \\
\text { şehre } \\
\text { mesafesi }\end{array}$ & Amaç & $\begin{array}{l}\text { Esnaflar için Katılım } \\
\text { Şartları }\end{array}$ \\
\hline $\begin{array}{l}\text { Butter } \\
\text { Tart Trail }\end{array}$ & $\begin{array}{l}\text { Bir Grup } \\
\text { Turizmci }\end{array}$ & Wellington & $\begin{array}{l}\text { - Toronto } \\
\text {-bir saat }\end{array}$ & $\begin{array}{l}\text {-Tur düzenlemek } \\
\text {-Wellington kırsalında } \\
14 \text { 'ten fazla tart çeşidi ve } \\
\text { diğer pasta türlerini } \\
\text { tatmak, çeşitli pastane ve } \\
\text { mutfak gezileri } \\
\text {-Yerel pazarda, alışveriş } \\
\text { yapmak } \\
\text {-Çeşitli çiftlik } \\
\text { ziyaretlerinde bulunmak }\end{array}$ & $\begin{array}{l}\text {-Tartlar ev yapımı olmalı } \\
\text {-Esnaf ürünleri orijinal } \\
\text { olmalı } \\
\text {-antikacılar ve bitpazarı } \\
\text { esnafı katılabilir } \\
\text {-Hediyelik eşya } \\
\text { mağazaları katılamaz } \\
\text {-Tezgahlar yoğun yaz } \\
\text { döneminde çoğunlukla } \\
\text { açık olmalı }\end{array}$ \\
\hline $\begin{array}{l}\text { Feast of } \\
\text { Fields }\end{array}$ & $\begin{array}{l}\text { Michael } \\
\text { Standler } \\
\text { ve Jamie } \\
\text { Kennedy }\end{array}$ & Vancouver & $\ldots$ & $\begin{array}{l}\text {-Tarımsal etkinliklerle } \\
\text { insanların dikkatini } \\
\text { çekmek ve dünya } \\
\text { sağlığına katkıda } \\
\text { bulunmak } \\
\text {-Mevsiminde yetişmiş } \\
\text { taze ve yerli yiyecekleri } \\
\text { yemek dışında bu } \\
\text { etkinliğin kar amacı } \\
\text { yoktur }\end{array}$ & $\begin{array}{l}\text {-Tarım sektörünü } \\
\text { destekleyen restoranlar, } \\
\text { şarap/bira, yiyecek } \\
\text { üreticileri davet edilir } \\
\text {-Bilet alan herkes } \\
\text { gelebilir }\end{array}$ \\
\hline $\begin{array}{l}\text { Food } \\
\text { Fanciers' } \\
\text { s Foray }\end{array}$ & & Amish & $145 \mathrm{~km}$ & $\begin{array}{l}\text {-Insanların Amish'i ve } \\
\text { yerel yiyecekleri } \\
\text { tanımalarını sağlamak } \\
\text {-Topluluk ve iş } \\
\text { çevrelerinin dikkatini } \\
\text { çekmek } \\
\text {-Yerel ürün satışı yapmak } \\
\text { ve ziyaretçilerin kalış } \\
\text { sürelerini uzatmak }\end{array}$ & $\begin{array}{l}\text {-Reklam, gezi ya da } \\
\text { katılımcıların kimler } \\
\text { olacağını kongre ve } \\
\text { ziyaretçi bürosu belirler } \\
\text {-Duyurular web sitesinde } \\
\text { yayınlanmaktadır }\end{array}$ \\
\hline
\end{tabular}


Tablo 2'nin Devamı

\begin{tabular}{|c|c|c|c|c|c|}
\hline $\begin{array}{l}\text { Food } \\
\text { Link:Tast } \\
\text { e Local, } \\
\text { Taste } \\
\text { Fresh }\end{array}$ & $\begin{array}{l}\text { Kar amacı } \\
\text { olmayan } \\
\text { bir kurum } \\
\text { olarak } \\
2002 \text { de } \\
\text { kuruldu }\end{array}$ & Wellington & $\ldots \ldots \ldots$ & $\begin{array}{l}\text {-Çiftçilere maddi kazanç } \\
\text { sağlamak } \\
\text {-Ziyaretçilerin yerel } \\
\text { ürünleri tatmasını } \\
\text { sağlamak } \\
\text {-Tüketiciyi eğitmek } \\
\text {-Çiftlik-üretici-restoran } \\
\text { arasında ilişki oluşturmak } \\
\text {-Yerel ürünlerin gerçek } \\
\text { değeri hususunda halkın } \\
\text { ilgisini arttırmak } \\
\text {-Bir kurum olarak } \\
\text { Foodlink'in sermayesini } \\
\text { arttırmak }\end{array}$ & $\begin{array}{l}\text {-Foodlink üretim } \\
\text { politikası ya da yiyecek } \\
\text { eylemi ile ilgili değildir. } \\
\text { - Yerel çiftliklerin yararını } \\
\text { gözetmektedir } \\
\text {-Kalite halk sağlığı için } \\
\text { önemlidir }\end{array}$ \\
\hline
\end{tabular}

Tablo 3' te gezi planı, ziyaretçi sayısı ve ziyaretçilerin etkinliklere katılım bedellerine ilişkin bilgiler özetlenmektedir.

Tablo 3: Etkinliklerin İçeriği ve Katılım Şartları

\begin{tabular}{|c|c|c|c|c|}
\hline $\begin{array}{l}\text { Etkinlik } \\
\text { Adı }\end{array}$ & Katılım Ücreti & Gezi Lojistiği & Katılım Bedeli & $\begin{array}{l}\text { Tahmini } \\
\text { Katılımcı } \\
\text { Sayısı } \\
\end{array}$ \\
\hline $\begin{array}{l}\text {-Butter Tart } \\
\text { Trail }\end{array}$ & - Ücretsiz & $\begin{array}{l}\text {-70 km - iki özel hafta sonu } \\
\text { (1 Temmuz ve Noel'den önceki hafta } \\
\text { sonu) olmak üzere yapılan rehbersiz tur } \\
\text {-Gezi rotası kaldııım taşlı ve çakıl taşlı } \\
\text { yolları gösterirken alternatif yolları da } \\
\text { içermektedir. } \\
\text {-Bisikletçiler için alternatif yollar } \\
\text { önerilmektedir. } \\
\text {-Aileler için yılda bir defa (yarım günlük) } \\
\text { ödüllü bisiklet etkinliği düzenlenir }\end{array}$ & -Ücretsiz & $\begin{array}{l}-55000 \text { broşür } \\
\text { dağıtılmaktadır }\end{array}$ \\
\hline $\begin{array}{l}\text { Feast of } \\
\text { Fields }\end{array}$ & $\begin{array}{l}\text { - Bilet alan herkes } \\
\text { gelebilir } \\
\text { (Kişi başı 80\$) }\end{array}$ & $\begin{array}{l}\text {-Birbirinden farklı yerde olmak üzere } \\
\text { yılda üç etkinlik var }\end{array}$ & $\begin{array}{l}\text {-Bilet alan } \\
\text { herkes gelebilir }\end{array}$ & $\begin{array}{l}-1000 \\
\text { civarında }\end{array}$ \\
\hline $\begin{array}{l}\text { Food } \\
\text { Fanciers's } \\
\text { Foray }\end{array}$ & - Ücretsiz & -Farklı temalarda birden çok gezi var & -Ücretsiz & ---- \\
\hline $\begin{array}{l}\text { Food } \\
\text { Link:Taste } \\
\text { Local, } \\
\text { Taste Fresh }\end{array}$ & $\begin{array}{l}\text { - Ücretsiz } \\
\text { - Çiftlikler için } \\
\text { kayıt ücreti } 85 \$ \text {, } \\
\text { 'Early Birds' kayıt } \\
\text { ücreti ise } 75 \$ \text { \$için }\end{array}$ & $\begin{array}{l}\text {-Yerel ve taze ürün tat etkinliği } \\
\text { genellikle pazar öğleden sonra yapılan } \\
\text { bir günlük bir festival } \\
\text {-Festivalin yeri her yıl değişmekte. } \\
\text {-2009 yılı itibariyle } 30 \text { farklı } \\
\text { restaurant/catering firması ve } 25 \\
\text { çiftlik/üretici } \\
\text {-Etkinliğin ana sponsoru Kitchener } \\
\text {-Foodlink kendi etkinlik sigortasını satın } \\
\text { alır } \\
\text {-Foodlink etkinlik öncesinde halk sağlığı } \\
\text { ve yiyecek denetçileri ile birlikte çalışır }\end{array}$ & $\begin{array}{l}\text {-Biletler kişi başı } \\
55 \$\end{array}$ & $\begin{array}{l}-2008 \text { de } 510 \\
\text { kişi }\end{array}$ \\
\hline
\end{tabular}

Tablo 4' te ise etkinliğin başka aktivitelerle desteklenip desteklenmediği, bütçesi ve pazarlanma stratejilerine ilişkin bilgiler yer almaktadır. 
Tablo 4: Etkinliklerin Pazarlanma Stratejileri

\begin{tabular}{|c|c|c|c|c|c|}
\hline $\begin{array}{l}\text { Etkinlik } \\
\text { Adı }\end{array}$ & $\begin{array}{c}\text { Ana /Yan } \\
\text { Aktivite }\end{array}$ & Bütçe/ Fon/ Yatırım & $\begin{array}{c}\text { Medyanın } \\
\text { Katılımı }\end{array}$ & $\begin{array}{c}\text { Pazarlama } \\
\text { Stratejileri ve } \\
\text { Etkinliğin } \\
\text { Ekonomik Çıktıları }\end{array}$ & Üretici/Şef İlişkisi \\
\hline $\begin{array}{l}\text { Butter } \\
\text { Tart } \\
\text { Trail }\end{array}$ & $\begin{array}{l}\text { - Yerel ürün } \\
\text { satışı } \\
\text { - Bit pazarı } \\
\text { ürünleri, el } \\
\text { sanatları ve } \\
\text { yerli yiyecek } \\
\text { satışı }\end{array}$ & $\begin{array}{l}\text { - İlk başlarda } \\
\text { işletmelerin etkinlik } \\
\text { planına katılımı } \\
\text { ücretsizdi, ancak } \\
\text { şimdi her bir durak } \\
\text { noktası için } 100 \$ \text { ve } \\
\text { planın reklam } \\
\text { satışından ek gelir } \\
\text { elde edilmektedir } \\
\text { - Gezi planını } \\
\text { yapmak aşağı yukarı } \\
15000 \text { \$a mal } \\
\text { olmaktadır } \\
\text { - Belediyenin } \\
\text { yönetim dahil pek } \\
\text { çok konuda desteği } \\
\text { var }\end{array}$ & $\begin{array}{l}\text { - Bölgede } \\
\text { etkinliğin tek } \\
\text { oluşu ulusal } \\
\text { medyanın } \\
\text { ilgisini çok fazla } \\
\text { çekmektedir. }\end{array}$ & $\begin{array}{l}\text { - Temmuz etkinliği } \\
\text { broşürlerle duyurulur } \\
\text { - Gezi üyeleri özel } \\
\text { etkinlikler yapar } \\
\text { - Noel için özel } \\
\text { promosyonlar var; } \\
\text { üyeler ve diğer } \\
\text { işletmeler katılım } \\
\text { ücreti öderler } \\
\text { - } 55000 \text { broşür } \\
\text { dağıtımaktadır } \\
\text { - Etkinliğin etkisini } \\
\text { tam olarak ölçmek } \\
\text { zordur. }\end{array}$ & $\begin{array}{l}\text { - Pastacıların etkinliğe } \\
\text { katılımı şeflerden çok } \\
\text { daha fazla } \\
\text {-17 gezi durağından } \\
\text { 7'si tarım üreticisi: } \\
\text { sabundan peynire, } \\
\text { şuruptan bitki } \\
\text { döşemeye kadar pek } \\
\text { çok ürün çeşidinin } \\
\text { sunulduğu alanlar }\end{array}$ \\
\hline $\begin{array}{c}\text { Feast of } \\
\text { Fields }\end{array}$ & $\begin{array}{l}\text {-Tarım ve } \\
\text { yerel yiyecek } \\
\text { satışı } \\
\text { - Üç farklı } \\
\text { çiftlik turu } \\
\text { - sebze, } \\
\text { meyve satışı } \\
\text { - Açık } \\
\text { arttırma ve } \\
\text { ürün satışı }\end{array}$ & $\begin{array}{l}\text { - Her etkinlik için } \\
\text { farklı bütçe } \\
\text { - Whistler'de kira } \\
\text { bedeli yok } \\
\text { - Yaklaşık 25000\$ }\end{array}$ & $\begin{array}{l}\text {-Medyayla ilişki } \\
\text { çok iyi } \\
\text {-Medya bu } \\
\text { etkinliklere } \\
\text { sponsor } \\
\text { olmaktadır. } \\
\text { Karşılığında } \\
1000 \text { kişilik } 60 \\
\text { adet ücretsiz } \\
\text { geçiş hakkı } \\
\text { almaktadır }\end{array}$ & $\begin{array}{l}\text {-2008 de üç } \\
\text { etkinliğin ikisinin } \\
\text { biletleri pek çok } \\
\text { medya kuruluşunun } \\
\text { da katkısıyla } \\
\text { tamamen satılmıştır }\end{array}$ & $\begin{array}{l}\text { - Etkinlik günü çiftçiler } \\
\text { restoran şefleriyle } \\
\text { ortak çalışmaktadır: } \\
\text { Bu sayede restoranlar } \\
\text { tüketiciye çiftçilerle } \\
\text { özel bir ilişki içinde } \\
\text { oldukları imajını } \\
\text { verirken tarım } \\
\text { ekonomisine ve yerel } \\
\text { topluma katkıda } \\
\text { bulunmuş olmaktadır. }\end{array}$ \\
\hline $\begin{array}{l}\text { Food } \\
\text { Fanciers } \\
\text { 's Foray }\end{array}$ & $\begin{array}{l}\text {-Yerli } \\
\text { yiyeceklerin } \\
\text { yenilmesi } \\
\text { - Bahçe } \\
\text { tasarımı } \\
\text { - Yerli } \\
\text { mobilya } \\
\text { ürünleri }\end{array}$ & $\begin{array}{l}\text {-Toplantı ve ziyaretçi } \\
\text { bürosu } \\
\text { destinasyonun } \\
\text { pazarlama kuruluşu } \\
\text { ve } 30 \text { ya da daha } \\
\text { fazla odalı otellerin } \\
\text { ziyaretçilerden aldığı } \\
\text { vergi bedeli ile } \\
\text { desteklenmektedir }\end{array}$ & $\begin{array}{l}\text {-Dergi ve } \\
\text { televizyon } \\
\text { programlarının } \\
\text { desteği çok } \\
\text { fazla }\end{array}$ & $\begin{array}{l}\text {-Etkinliğin web } \\
\text { sitesinde bulunan } \\
\text { gezi planı ve indirme } \\
\text { seçeneği çok } \\
\text { popüler, } 2008 \text { de } \\
\text { toplam } 2627 \text { indirme } \\
\text { yapılmıştır }\end{array}$ & $\begin{array}{l}\text { - Üreticiler çok ön } \\
\text { planda tutulmazken, } \\
\text { restoranlar, aile } \\
\text { restoranları ve } \\
\text { spesiyaller dikkat } \\
\text { çekmektedir (ancak } \\
\text { yerel yemek hikayeleri } \\
\text { açıkça } \\
\text { anlatılmamaktadır) } \\
\text { - Yerel halkla birlikte } \\
\text { yapılan yemek } \\
\text { etkinlikleri yaygındır. }\end{array}$ \\
\hline $\begin{array}{l}\text { Food } \\
\text { Link:Tas } \\
\text { te Local, } \\
\text { Taste } \\
\text { Fresh }\end{array}$ & $\begin{array}{l}\text { - Yerel } \\
\text { yiyeceklerin } \\
\text { tüketilmesi } \\
\text { - çiftlikte } \\
\text { yerel ürün } \\
\text { satışı }\end{array}$ & $\begin{array}{l}\text { - Etkinlik finansmanı } \\
\text { Trillium Foundation } \\
\text { adlı bir vakıfca } \\
\text { yapılmaktadır } \\
\text { - } 2006 \text { yılında } 5 \text { yıllık } \\
\text { bütçe } 117000 \$ \\
\text { olarak tahmin } \\
\text { edilmiştir. } \\
\text { - } 2005 \text { yılında } \\
\text { etkinlik planı üretim } \\
\text { ve dağıtım için } \\
23500 \$ a \text { mal oldu, } \\
\text { bu fonun \%61i ücret } \\
\text { ve reklama ayrıldı }\end{array}$ & $\begin{array}{l}\text { - Medya ile } \\
\text { iletişim ve ilişki } \\
\text { kurmak zaman } \\
\text { almakta }\end{array}$ & $\begin{array}{l}\text {-Yerel yiyeceklerin } \\
\text { önemi, yararları ve } \\
\text { nerede } \\
\text { bulunabileceği } \\
\text { hususunda } \\
\text { tüketicilere bilgi } \\
\text { sağlanmaktadır } \\
\text { - Gezi planlarının } \\
\text { yaklaşık bir çeyreği } \\
\text { ticari showlarda, } \\
\text { fuarlarda ve } \\
\text { etkinliklerde } \\
\text { dağıtılmaktadır } \\
\text { - Çiftliklerde } \\
\text { ürünlerin doğrudan } \\
\text { satışı mevcuttur } \\
\end{array}$ & $\begin{array}{l}\text { - Yerel ürünlerin } \\
\text { restoranlara dağıtımı } \\
\text { - Etkinlik için } \\
\text { çevredeki çiftliklerin } \\
\text { yalnızca bir kısmı ile } \\
\text { işbirliği yapııı }\end{array}$ \\
\hline
\end{tabular}

Kaynak: Piebiak, (2008). 


\section{Sonuç ve Öneriler}

Tarihte pek çok kültür ve medeniyete ev sahipliği yapmış olan Türkiye, kültürel çeşitlilik açısından çok zengindir. Bunlar içinde kırsal alanların sahip olduğu yerel kültüre ait gastronomi değerleri ise ayrı bir öneme sahip olup, turizmde bir fırsat olarak değerlendirilmelidir. Ancak yerel kültürlere ait değerlerin etkinlikler yoluyla turizme kazandırılması yapılacak etkinlik planlaması ile mümkün olacaktır. Bu sayede kırsal alanların sürdürülebilir turizm gelişimlerinden söz edilebilir. Nitekim Amerika ve Kanada kırsallarında düzenli olarak yapılan etkinliklerin incelendiği bu çalışmada etkinlik planlarından elde edilen bilgiler de bu ifadeyi doğrulamaktadır. Özellikle büyük yerleşim alanlarına yakın kırsal yerleşkelerde yapılan bu etkinlikler bölgenin tespit edilen turizm potansiyelleri doğrultusunda ve belli bir plan dahilinde tamamlayıcı diğer aktivitelerle desteklenerek değerlendirilmektedir. Birtakım tarımsal aktivitelerle insanların dikkatinin yerel ürünlere çekildiği bu etkinliklerde öncelikle yerel halkın ekonomik kazanç sağlaması ve yörelerin tanıtımının yapılması amaçlanmaktadır. Sonuç olarak bu etkinliklerin en önemli iki kazanımı ise çiftçi, yemek üreticisi ve yerel halk ile ziyaretçi memnuniyetinin sağlanmış olmasıdır.

$\mathrm{Bu}$ çalışmanın mekânsal turizm planlaması kapsamında Türkiye kırsallarının sürdürülebilir kalkınması için yemek kültüründen nasıl faydalanılabileceği hususuna ışık tutacağı düşünülmektedir.

Kanada ve Amerika Birleşik devletlerinin üç farklı kırsalında, uzun yıllardır düzenli olarak yapılan kırsal turizm ve gastronomi etkinlik planları incelendiğinde, Türkiye'de turistik potansiyelleri bulunan kırsal alanların ekonomik, sosyal ve kültürel açıdan kalkınmasında yemek kültüründen nasıl faydalanılacağı hususunda şu öneriler verilebilir; önemlidir

- Etkinlik planlanan kırsalın turistik potansiyellerinin önceden belirlenmesi

- Etkinlik binalar ve yerleşkeler açısından kırsal ölçekte ve küçük çaplı olmalıdır.

- Sürdürülebilir olmalı - bölgenin kırsal yapısı değişmemeli ve kaynakların kullanımı açısından da gelişimi sürdürülebilir olmalıdır. Kırsal turizm, şehirleşme ve büyüme aracı olmak yerine, potansiyel bir koruma ve sürdürülebilirlik aracı olarak görülmelidir.

- Sürdürülebilirlik ve yerel yiyecek kültürünün korunması gereklidir.

- Yerel ürünlerle ilgili markalaşma sağlanmalı ve coğrafi işaretlemeler yapılmalıdır.

- Yerel yiyeceklerin ve içeceklerin sunumu önemlidir.

- Yemek pişirme, yemeklerle ilgili ipuçları verme, yemek hazırlama sürecine ziyaretçilerin katılımının sağlanması gereklidir ve yerel yiyecek satışı bizzat çiftliklerde ya da otantik pazarlarda olmalıdır.

- Gastronomi ve turizm arasında yeni bağlantılar oluşturulması için yerel kurumlar önemlidir.

- Gastronomi turizmini geliştirecek sistematik bir çalışma için; tarih, coğrafi sınırlar, ekonomik ön koşullarla yerel yiyecek-içecek kültürünün bir değerlendirmesi yapılmalıdır.

- Etkinlik öncesinde gezi ve etkinlik planı hazırlanmalı ve plan ilgili web sitesinde resim ve videolarla ilgi çekici hale getirilmelidir.

- Etkinlik yapılacak kırsal bölge ana şehirlere yakın olmalıdır. 
- Etkinlikler en fazla bir günlük süre ile sınırlı tutulmalıdır.

- Yapılacak turlar birbirine yakın birden fazla güzergâhı kapsayabilir. olabilir.

- Durak noktalarının bir önceki gezi etkinliğinden farklılık göstermesi ilgi çekici

- Çiftçi, yemek üreticileri ve yerel halkın etkinlikten kazanç sağlaması önemlidir.

- Yiyecek ve seyahatle ilgili TV, radyo vb. tanıtım programları ile medyanın etkinliğe desteği sağlanmalıdır.

- Etkinlik yapılacak turlara yakın şehirlerden ulaşım ücretsiz olabilir.

- Gastronomi etkinlikleri tek başına yeterli olamaz ve yarışmalar, yürüme, tırmanış, bisiklet, olta balıkçılığı, tarımsal etkinliklere katıım gibi tamamlayıcı diğer aktivitelerle desteklenmelidir.

- Tüketici, çiftçi ve diğer katılımcıları yerel yiyeceklerin faydaları hususunda bilgilendirilmesi gereklidir.

- Gıda güvenliği ve kalite önemlidir.

- Çiftçi, esnaf, yerel halkın ziyaretçilerle iletişim konusunda bilinçlendirilmesi önemlidir.

- Tüm bu çalışmalar yasal bir zemine oturtulmalıdır.

\section{Kaynakça}

Ardabili, F.S., Rasouli, E., Daryani, S.M., Molaie, M. ve Sharegi, B. (2011). 'The Role of Food and Culinary Condition in Tourism Industry', Middle-East Journal of Scientific Research, 9 (6), ss. 826-833.

Aref, F ve Gill, S.S. (2009). 'Rural Tourism Development through Rural Cooperatives', Nature and Science, 7(10).

Aslan, A.(2008). 'Turizm Planlamasına Yerel Toplumun Katılımı: Saklı Bahçe Akyaka Üzerine Bir İnceleme', Anatolia: Turizm Araştırmaları Dergisi, 19 (1), ss. 71-83.

Bahçe, A.S. (2013).Alternatif Turizm, I.baskı, Eskişehir: Anadolu Üniversitesi.

Deveci, B., Turkmen, S.,ve Avcıkurt, C.(2013). 'Kırsal Turizm Ille Gastronomi Turizmi İlişkisi: Bigadiç Örneği', International Journal of Social and Economic Sciences, 3 (2), ss. 29-34.

Everett,S ve Aitchison, C. (2008). 'The Role of Food Tourism in Sustaining Regional Identity: A Case Study of Cornwall, South West England, Journal of Sustainable Tourism, 16 (2), ss.150-167.

Hall, C.M., Mitchell, R. ve Sharples,L. (2003), 'Consuming places: the role of food, wine and tourism in regional development'lçinde Hall, C.M., Sharples, L., Mitchell, R., Macionis, Cambourne, B, (Editörler) Food Tourism Around the World:Development, Management And Markets, ss. 25-59, Butterworld Heinemann: Burlington.

Hall, C.M., Mitchell, R. ve Sharples,L. (2003), 'The consumption of experiences or the experience of consumption? An introduction to the tourism of taste' Içinde Hall, C.M., Sharples, L., Mitchell, R., Macionis, Cambourne, B, (Editörler) Food Tourism Around the World:Development, Management And Markets, ss.1-25, Butterworld Heinemann: Burlington.

Holloway.J, Humphreys C ve Davidson R.(2009), The Business of Tourism, Edinburgh Gate Harlow Essex CM20 2JE England: Pearson Education Limited.

Hong, W-C. (1998). Rural Tourism: A Case Study of Regional Planning in Taiwan.(Online),http://fftc.imita.org/htmlarea_file/library/20110726110810/eb456. pdf.Erişim:11.01.14.

Kalinia, A. (2013). 'Branding Sicily as Gastronomically Attractive Destination, Viewed by Kempinski Hotel Giardino di Costanza', Saimaa University of Applied Sciences Tourism and Hospitality, Imatra Degree Programme in Tourism. 
Kesici, M. (2012). Kırsal Turizme Olan Talepte Yöresel Yiyecek ve İçecek Kültürünün Rolü', KMÜ Sosyal ve Ekonomik Araştırmalar Dergisi, 14 (23), ss. 33-37.

Kiper, T.,ve Özdemir, G. (b.t). 'Tourism Planning in Rural Areas and Organization Possibilities', Namık Kemal University, Faculty of Agriculture, Department of Landscape Architecture, Department of Agricultural Economics.

Lane, B. (2005). 'Sustainable Rural Tourism Strategies: A Tool For Development and Conservation, Interamerican Journal of Environment and Tourism, 1(1).

Lee, A. (2012). The Creative Food Economy and Culinary Tourism through Place Branding: 'TERROIR' into a Creative and Environmentally Friendly Taste of Place, Unpublished Doktorate Thesis, University of Waterloo, Ontario, Canada.

MacDonald, R ve Jolliffe, L. (2003). 'Cultural Rural Tourism Evidence From Canada, Annals of Tourism Research, 30 (2), ss. 307-322.

Hall, C.M., Sharples, E., Mitchell, R., Cambourne, B., \& Macionis, N. (2003), Food Tourism Around the World;Development, Management and Markets,1.Ed, Butterworth-Heinemann/Elseiver, Oxford.

Michela C. M. ve Adriano P. (2009). 'Celebrating Local Products: The Role of Food Events', Journal of Foodservice Business Research, 12(4),ss. 364-383.

Matlovicova. K. ve Pompura M. (2013). 'The Culinary Tourism in Slovakia: Case Study of the Traditional Local Sheep's Milk Products in the Regions of Orava and Liptov'. GeoJournal of Tourism and Geosites, 2(12),ss.129-144.

Mihailovic, B.ve Moric, I. (2012). 'The role of Marketing philosophy in Rural Tourism Development'. Tourism and Hospitality Management, 18(2), ss. 267-279.

Okumuş, B., Okumuş, F.,ve McKrecher B. (2007). 'Incorporating local and international cuisines in the marketing of tourism destinations: The cases of Hong Kong and Turkey'. Tourism Management, 28, ss. 253-261.

Özdemir, G. (2006 ). 'Resort Planlaması: Turizm Planlaması İçindeki Yeri ve Önemi'. Journal of Yaşar University, 1(3), ss. 239-253.

Piebiak, M. (2008). Regional Food Cluster Review, A Federal Provincial Territorial Initiative, Canada: Alberta.

Rand, G. E. D., Heath, E ve Alberts, N. (2003). 'The Role of Local and Regional Food in Destination Marketing', Journal of Travel \& Tourism Marketing, 14(3-4), ss. 97-112.

Soykan, F. (2000). 'Turizm Coğrafyası ve Turizm Planlaması'. Ege Coğrafya Dergisi, 11(2000), ss. 39-55.

Torun, E.(2013). 'Kırsal Turizmin Bölge İnsanına Katkıları', KMÜ Sosyal ve Ekonomik Araştırmalar Dergisi, 15 (24), ss. 31-37.

Uysal M. ve Baloğlu Ş. (1994). 'Destinasyonun Yaşam Süresi İle Taşıma Kapasitesi Arasındaki İlişki', Anatolia, ss. 36-42.

Yozukmaz, N., Ekiztepe, B.A. ve Çeken, H. (2014). 'The Importance of Rural Tourism: Rural Tourism Practices in the World and in Turkey', International Journal of Social and Economic Sciences, 4 (2), ss. 37- 44.

Yıldırım, A.ve Şimşek, H. (2011). Sosyal Bilimlerde Nitel Araştırma Yöntemleri, Ankara: Seçkin Yayıncılık. 